\author{
Pawet Ochocki \\ Uniwersytet Papieski Jana Pawta II w Krakowie \\ Wyższe Seminarium Duchowne Archidiecezji Krakowskiej
}

\title{
Organy w Wyższym Seminarium Duchownym Archidiecezji Krakowskiej
}

Sobór Watykański II, nawiązując do tradycji muzycznej Kościoła, orzekł, że w Kościele łacińskim należy mieć $\mathrm{w}$ wielkim poszanowaniu organy piszczałkowe, które dodają ceremoniom kościelnym majestatu, podnosząc umysły wiernych do Boga i spraw niebieskich ${ }^{1}$. Warto również, poza tym wszystkim, co jest związane z czysto praktycznym wykorzystaniem organów w liturgii, rozważyć teologiczny wymiar tego instrumentu.

Benedykt XVI w jednym ze swoich przemówień ukazał wspólnotę Kościoła na przykładzie budowy organów ${ }^{2}$ :

Tak jak w przypadku organów, ręka organmistrza musi wciąż na nowo dostrajać je do właściwego brzmienia, tak i my, w Kościele, mimo różnorodności darów i charyzmatów, winniśmy dążyć do pełnej zgodności i jedności w uwielbieniu Boga i braterskiej miłości.

Ta nieustanna przemiana, usuwająca spośród nas wszelkie dysharmonie, dokonuje się w liturgii, której integralną częścią jest muzyka. Pojawienie się instrumentu piszczałkowego w seminaryjnej kaplicy miało w tym teologicznym kontekście szczególne znaczenie. Seminarium jest przecież miejscem formacji tych, którzy w celebracji liturgii odgrywać będą zasadniczą rolę. Organy są duchowym obrazem wspólnoty Kościoła, także wspólnoty seminaryjnej, której członkowie w pełnej zgodności, jedności i braterskiej miłości, uwielbiają Boga w czasie sprawowanej liturgii.

Organy w seminarium są również bardzo konkretną odpowiedzią na postulaty stawiane przez soborowe dokumenty, mówiące o liturgicznej formacji przyszłych

Zob. Święta Kongregacja Obrzędów, instrukcja Musicam Sacram, 62.

2 Miało to miejsce 13 września 2006 roku w Starej Kaplicy (Alte Kapelle) w Ratyzbonie w czasie ceremonii poświęcenia nowych organów. 
kapłanów. Zgodnie z konstytucją o liturgii należy przywiązywać dużą wagę do teoretycznego i praktycznego wykształcenia muzycznego w seminariach ${ }^{3}$. Liturgia sprawowana w domu formacji przyszłych duchownych winna być przygotowana i celebrowana w sposób wzorcowy. Dzięki instrumentowi piszczałkowemu w czasie liturgii może już rozbrzmiewać, w myśl liturgicznych zaleceń Kościoła, żywa muzyka, godna wielkiego Misterium Eucharystii.

Budowa organów w seminarium miała również wiele, zdawałoby się prozaicznych, ale w gruncie rzeczy ważnych aspektów. Instrument budowany był w styczniu tego roku, w czasie pobytu alumnów w seminarium. To sprawiło, że wszyscy klerycy po części uczestniczyli w tym wydarzeniu. Niektórzy z ciekawością sami przychodzili na chór, obserwując pracę organmistrzów. Wielu wzięło udział w zorganizowanej prelekcji, dotyczącej budowy i pielęgnacji organów. Jest to na pewno bardzo pozytywny wkład w budowaniu muzycznej świadomości alumnów, którzy za kilkanaście lat staną się osobami odpowiedzialnymi za stan instrumentów w kościołach naszej archidiecezji. Warto dodać, że organoznastwo wpisane jest w plan wykładów i ćwiczeń z muzyki kościelnej, studiowanej przez kleryków przez sześć lat.

Demontażem, sprowadzeniem instrumentu z Norwegii i jego montażem na chórze seminaryjnej kaplicy zajęła się firma pana Mariana Majchera In Plenum Pl. Firma ta prowadzi działalność od 1996 roku i od tej chwili zajmuje się wyłącznie budową, przebudową oraz remontami organów piszczałkowych. Od początku swojego istnienia zbudowano kilkadziesiąt instrumentów (na bazie wcześniej powstałych organów) pozyskanych ze świątyń niemal całej Europy. Firma zatrudnia obecnie 4 pracowników. Dwóch z nich posiada dyplom mistrzowski w tym zawodzie, dwóch pozostałych długoletnie doświadczenie, które pozwala na uzyskanie dyplomu czeladnika i mistrza. Początki firmy związane są z budową używanego instrumentu niemieckiej firmy „Klais” w Gołkowicach (diecezja katowicka). Oferta firmy spotkała się wówczas z akceptacją prof. Juliana Gembalskiego, ówczesnego rektora Akademii Muzycznej w Katowicach.

Prace organmistrzowskie w krakowskim seminarium rozpoczęto z początkiem stycznia 2014 roku. Instrument został oddany do użytku przy udziale Diecezjalnej Komisji ds. Muzyki Kościelnej 31 stycznia 2014 roku. Poświęcenie organów dokonało się w Uroczystość Zmartwychwstania Pańskiego, 20 kwietnia 2014 roku, przed uroczystym Te Deum. Poświęcenia dokonał ks. kard. Stanisław Dziwisz. Po poświęceniu pan dr Witold Zalewski wykonał Preludium i Fugę Es-dur (BWV 552) Jana Sebastiana Bacha.

3 Zob. Sobór Watykański II, konst. Sacrosanctum Concilium, 15. 
Organy są instrumentem mechanicznym, 12-głosowym, zbudowanym w 1985 roku dla protestanckiego kościoła w Gjerivegen w Norwegii przez firmę J.H Jürgensen z Oslo. Do kaplicy seminaryjnej został ofiarowany przez ks. dra hab. Roberta Tyrałę.

\section{Dyspozycja organów}

$\begin{array}{lll}\text { I Manuał } & \text { II Manuał } & \text { Pedał } \\ \text { Rörflöyte 8' } & \text { Spissflöyte } & \text { 4' Pommer 4' } \\ \text { Principal 4' } & \text { Principal 2' } & \text { Subbass 16' } \\ \text { Mixtur 3 f } & \text { Nasat 11/3' } & \\ \text { Ged.flöyte } & \text { 4Gedact 8' } & \\ \text { Gemshorn 2' } & \text { Spissgamba 8' }\end{array}$

Połączenia: I-II, I-P, II-P

Tremolo

Wybitny organista i kompozytor Jan Sebastian Bach wiele swoich partytur opatrzył skrótem S.D.G, Soli Deo Gloria, co oznacza: „Bogu jedynemu chwała”. Z pewnością taka sama intencja i taki sam cel przyświecał wszystkim, którzy przyczynili się do tego, by w kaplicy seminarium duchownego w Krakowie rozbrzmiewały dziś dźwięki prawdziwych organów. Jestem zatem przekonany, że dzieło budowy organów w naszym seminarium można by opatrzyć podobną inskrypcją. 